\title{
NDRG1 regulates osteosarcoma cells via mediating the mitochondrial function and CSCs differentiation
}

\author{
Tong Zhao', Ying Meng ${ }^{2}$, Yongping Wang ${ }^{1}$ and Wenji Wang ${ }^{*}$
}

\begin{abstract}
Background: Cancer stem cells (CSCs) are mainly contributed to malignancy metastatic potential and resistant therapy of osteosarcoma (OS). The mitochondria-related apoptosis was generally accepted as the target of tumor therapy. However, the effect of N-myc downstream-regulated gene 1 (NDRG1) on CSCs and mitochondrial health in OS is still unknown.

Methods: In OS cells, MG63 and U2OS, the siRNA of NDRG1 were conducted. Transwell, western blot, RT-qPCR, and mitochondria isolation were used to identify the effect of NDRG on OS cells and mitochondria. Moreover, the differentiation-related factors of CSCs were determined.

Results: After downregulation of NDRG1, the cell viability, invasion ability decreased whereas cell apoptosis increased. The expressions profiles of fibronectin, vimentin, vascular endothelial growth factor (VEGF), matrix metalloproteinase (MMP) 2, MMP9, and MMP13 were downregulated, but E-cadherin expression level was upregulated by NDRG1 siRNA. At the same time, cytochrome (Cyt) C levels were increased in cytosol with the decreasing in mitochondria after siRNA treatment. The mitochondrial membrane potential (MMPs) was declined, and the function of mitochondria was impeded. The expressions of uncoupling proteins (UCP) 2, voltage dependent anion channel (VDAC), peroxisome proliferator-activated receptor gamma coactivator (PGC)-1a, and cyclooxygenase (COX) 2 were downregulated by NDRG1 silencing. Moreover, NDRG performed its function primarily through the Wnt pathway and could regulate the differentiation of osteosarcoma stem cells.

Conclusion: Silencing of NDRG1 could damage the function of mitochondria, promote the CSCs differentiation, alleviating OS progression.
\end{abstract}

Keywords: Cancer stem cell, N-myc downstream regulated 1, Osteosarcoma, Mitochondria-mediated apoptosis

\section{Introduction}

Osteosarcoma (OS) is well known as a primary, high malignancy, and metastatic potential bone tumor $[1,2]$. Although the use of neoadjuvant chemotherapy has improved the 5-year survival rate of OS patients, the prognosis remains poor. Therefore, identifying new early

\footnotetext{
* Correspondence: wangwenji2019@163.com

'The First Hospital of Lanzhou University, No. 1 Dongggang West Road, Chengguan District, Lanzhou, Gansu, China

Full list of author information is available at the end of the article
}

diagnostic biomarkers and therapeutic targets are essential research goals for OS.

The metastasis inhibitor N-myc downstream-regulated gene 1 (NDRG1) is a stress response protein that is involved in the inhibition of multiple oncogenic signaling pathways. NDRG1 expression was regulated by multiple factors in both healthy and cancerous cells [3], and abnormal expression affected cell proliferation, differentiation [4, 5], migration, invasion, and stress responses [6]. The overexpression of NDRG1 was induced by hypoxia

(c) The Author(s). 2021 Open Access This article is licensed under a Creative Commons Attribution 4.0 International License, which permits use, sharing, adaptation, distribution and reproduction in any medium or format, as long as you give appropriate credit to the original author(s) and the source, provide a link to the Creative Commons licence, and indicate if changes were made. The images or other third party material in this article are included in the article's Creative Commons licence, unless indicated otherwise in a credit line to the material. If material is not included in the article's Creative Commons licence and your intended use is not permitted by statutory regulation or exceeds the permitted use, you will need to obtain permission directly from the copyright holder. To view a copy of this licence, visit http://creativecommons.org/licenses/by/4.0/ The Creative Commons Public Domain Dedication waiver (http://creativecommons.org/publicdomain/zero/1.0/) applies to the data made available in this article, unless otherwise stated in a credit line to the data. 
in various human cancers [7], like lung cancer, liver cancer, and brain cancer.

In recently, research found that regulation of NDRG1 could inhibit HGF and IGF-1signal, reduce cell migration and enhance the drug sensitive in pancreatic cancer, and NDRG1 expression could be repressed by miR1469-5p, regulating NF-kB pathway activity $[8,9]$. In prostate cancer, NDRG1 is phosphorylated by PIM1 to enhanced cell migration and invasion [10]. Cell apoptosis was induced by NDRG1 downregulation in HCC, and mitochondrial damage were induced by the upregulation of BAX and downregulation of Bcl-2 and Bcl-x [11]. Importantly, research found that NDRG1 promotes the stemlike properties of lung cancer cells through Skp2-mediated ubiquitination preventing the degradation of c-Myc [12]. NDRG1 overexpression promotes the progression of esophageal squamous cell carcinoma through regulating Wnt signaling pathway [13]. NDRG1 also regulated the molecular motor, decreased the migration ability, playing a role of anti-transfer in tumor cells [14]. The role of NDRG1 on OS cells was rarely revealed so far. Researches showed that NDRG1 expression abrogation sensitized OS cells to chemotherapy, increasing cells apoptosis [15].

According to previous researches, we hypothesized that the mitochondrial function and CSC differentiation could be regulated by changing the levels of NDRG1, alleviating the progression of OS. The aim of this study is to investigate the role of NDRG1 on mitochondria and CSCs of OS.

\section{Methods}

\section{Cell culture}

The human osteoblast cell line hFOB, human OS cell lines U2OS, and MG63 were purchased from the Shanghai Cell Bank of the Chinese Academy of Sciences. The cells were cultured at $37{ }^{\circ} \mathrm{C}$ and $5 \% \mathrm{CO}_{2}$, the medium of the cells respectively were DMEM/F12 (Hyclone) and RPMI 1640 (Hyclone), respectively and containing 10\%FBS (Gibco) and penicillin and streptomycin (100 U/ $\mathrm{mL}$, Gibco). Cells were passaged by digestion with $0.25 \%$ trypsin.

\section{RNA interference}

The NDRG1 (NCBI Accession No: NG_007943.1) sequence was obtained from GenBank, and used to design the NDRG1 siRNA sequence. Cells $\left(4 \times 10^{6}\right.$ cells $\left./ \mathrm{mL}\right)$ were washed with $1 \mathrm{~mL}$ of serum-free medium, passed on to 6-well cell culture plates. After incubating for 24 h, cells were transfected with NDRG1 siRNA and negative control (NC) and incubated with transfection reagent according to manufacturers' instructions. The transfection mixture was added to the wells, and the cell culture medium was changed after $24 \mathrm{~h}$. After $72 \mathrm{~h}$, cells were treated with $2.5 \mathrm{mg} / \mathrm{mL}$ puromycin for $96 \mathrm{~h}$ to select for stable transfection. Downregulation of NDRG1 expression was confirmed.

\section{Viability assays}

Single cell suspensions were prepared, and inoculated into 96-well plates. The corresponding treatments were added to each group of cells before $24 \mathrm{~h}$ incubation. Cells were then incubated with MTT (Beyotime), then culture medium was discarded, and the OD at $570 \mathrm{~nm}$ was measured.

\section{Invasion assays}

Transwell chambers were placed in 24-well cell culture plates. Plates were incubated at $37{ }^{\circ} \mathrm{C}$ and $5 \% \mathrm{CO}_{2}$ for $24 \mathrm{~h}$, containing single-cell suspension in upper chamber and medium supplemented with serum in lower chamber. Cells were washed, then fixed. A cotton swab was used to gently scrape off cells that did not migrate. Cells were stained with $0.1 \%$ crystal violet. The migration status of the cells was observed with a microscope.

\section{Mitochondrial isolation}

The isolation of mitochondria was performed according to the instructions of kits (Sigma). Namely, the cells were subjected to wash with phosphate buffer solution. Cells were resuspended with lysis buffer. After that, $1 \times$ extraction buffer was added before centrifuge. Then, the pellet was obtained.

\section{JC-1 assay}

The cells were incubated with JC-1 solution (Beyotime) at $37{ }^{\circ} \mathrm{C}, 30 \mathrm{~min}$. A microreader was used to obtain the fluorescence of MMPs at 540 and $490 \mathrm{~nm}$.

\section{Flow cytometry}

CD133+ positive cells were enriched by flow separation using magnetic activated cell sorting. Simply, sorting buffer was used to prepare cell suspension with density of $5 \times 10^{6}$ cells $/ \mathrm{mL}$. Subsequently, microbeads combined with mouse anti-Human CD133 antibody were added and incubated for $30 \mathrm{~min}$. Cells were washed and resuspended to separation.

\section{Sphere formation assay}

CD133+ cells were cultured in Dulbecco's Modified Eagle Medium/F12 medium plus with $20 \mathrm{ng} / \mathrm{ml} \mathrm{EGF,} 20$ $\mathrm{ng} / \mathrm{ml} \mathrm{bFGF}, 0.4 \% \mathrm{BSA}$, and $2 \%$ B27 for 500 cells/well. Tumor-sphere formation was used to identify CD133+ isolation.

\section{Western blot}

Proteins were extracted using radioimmunoprecipitation assay lysis buffer. After separation by sodium dodecyl 
sulfate polyacrylamide gel electrophoresis, the proteins were transferred to PVDF membrane, and blocked in 5\% skim milk in PBS containing 0.5\% Tween 20 for $1 \mathrm{~h}$, then the membrane was incubated with primary antibodies and secondary antibodies, and visualized by electrochemiluminescence. Semiquantitative grayscale data analysis was performed.

\section{qRT-PCR}

RNeasy Plus Universal Kits (QIAGEN) were used to extract total RNA of the cells. RNA purity and concentration were determined using a NanoDrop 2000 spectrophotometer. Reverse transcription was carried out using cDNA synthesis kit (QIAGEN). The quality of the data obtained was confirmed based on the amplification and melting curves. Relative mRNA expression was calculated using the formula $\mathrm{F}=$ $2^{-\Delta \Delta \mathrm{Ct}}$. Primer sequences are shown in Table 1 .

\section{Statistical analysis}

All data in this study were analyzed using the SPSS 20.0 software. The $t$ test and one-way analysis of variance were used to analyze statistical differences. $P$ values $<0.05$ were considered to indicate statistically significant results. n.s. means $\mathrm{p}>0.05,{ }^{*}$ mean $\mathrm{p}<0.05,{ }^{* * *}$ means $\mathrm{p}<0.01$.

\section{Results}

Silence of NDRG1 inhibited the proliferation and invasion of OS cells

In this study, the expression levels of NDRG1 in U2OS and MG63 were higher than hFOB, while the siRNA decreased the level of NDRG1 ( $p<0.01$ ). After transfection, the levels of NDRG1 in si-NC and NC were tripled comparing with si-NDRG1 (Fig. 1A). U2OS and MG63 cells apoptosis increased, cell viability and invasion ability decreased by siRNA (Fig. 1B, C, D). After siRNA depletion of NDRG1 in OS cells, the expression levels of VEGF, fibronectin, and vimentin were significantly decreased, whereas E-cadherin expression was significantly increased (all $p<0.01$; Fig. 1E). At the same time, the expression of MMP2, MMP9, and MMP13 was decreased when NDRG1 silencing (Fig. 1F). The results showed that siRNA interference inhibited OS cells viability, invasion, and migration progression.

\section{Downregulation of NDRG1 promoted mitochondria- mediated apoptosis}

The apoptosis of mitochondria-mediated was the leakage of CytC. Compared with control, U2OS and MG63, the levels of CytC were significantly increased in cytosol of cells subject to NDRG siRNA (Fig. 2A). Structure and function of mitochondria were affected by NDRG1 expression. The mitochondrial membrane potentials were declined, and UCP2, VDAC, PGC-1 $\alpha$, and COX2 were downregulated (Fig. 2B, C).

\section{NDRG1 regulated CSCs differentiation via Wnt signal}

The database of STRING was applied to predict the interaction between NDRG1, pluripotency, and Wnt signal (Fig. 3A). To demonstrate the effect of NDRG1 on OS CSCs, CD133+ positive cells were enriched by flow

Table 1 Primers sequences

\begin{tabular}{|c|c|c|}
\hline Gene & Forward & Reverse \\
\hline B-catenin & TGGTGCCCAGGGAGAACCCC & CCCACCCCTCGAGCCCTCTC \\
\hline NDRG1 & GGATCAGTTGGCTGAAAT & ATCTTGAGTAGGGTGGTCTT \\
\hline Bax & GGAGCTGCAGAGGATGATTG & CCAGTTGAAGTTGCCGTCAC \\
\hline $\mathrm{BCl}-2$ & CTGAGGAGCTTTGTTCAACCA & TCAAGAAACAAGGTCAAAGGGA \\
\hline Fibronectin & GGAGCAAATGGCACCGAGATA & GAGCTGCACATGTCTTGGGAAC \\
\hline Vimentin & TGCCGTTGAAGCTGCTAA CTA & CCAGAGGGAGTGAATCCAGAT TA \\
\hline VEGF & TTGCCTTGCTGCTCTACCTCCA & GATGGCAGTAGCTGCGCTGATA \\
\hline E-cadherin & AATGCCGCCATCGCTTAC & AGTTCGAGGTTCTGGTAGGG \\
\hline TCF 4 & TGGCCCTGAGAGGCAGCCAT & GGTCCTCATCGTCATTATTGCTAGAT \\
\hline LEF 1 & CCAGCTATTGTAACACCTCA & TTCAGATGTAGGCAGCTGTC \\
\hline LRP 5 & CAGCCTGACGCACCCCTTCG & СACCTCCTCGGCTCCTGCCT \\
\hline LRP 6 & GCTGGAATGGATGGTTCAAGTCG & CAGAATGGATTTCACGCAGACCC \\
\hline Wnt 3a & GTTGGGCCACAGTATTCCTC & ATCCCACCAAACTCGATGTC \\
\hline Runx2 & AAGCTTGATGACTCTAAACC & TCTGTAATCTGACTCTGTCC \\
\hline Osterix & TGAGGAGGAAGTTCACTATG & CATTAGTGCTTGTTAAAGGGG \\
\hline Dlx5 & GCATTACAGAGAAGGTTTCAG & TTTCACCTGTGTTTGTGTGTC \\
\hline Coll I & GCTATGATGAGAAATCAACCG & TCATCTCCATTCTITCCAGG \\
\hline B-actin & TGGCATTGCCGACAGGATGCAGCAA & СTCCTCATACTCCTGCTTGCTGAT \\
\hline
\end{tabular}



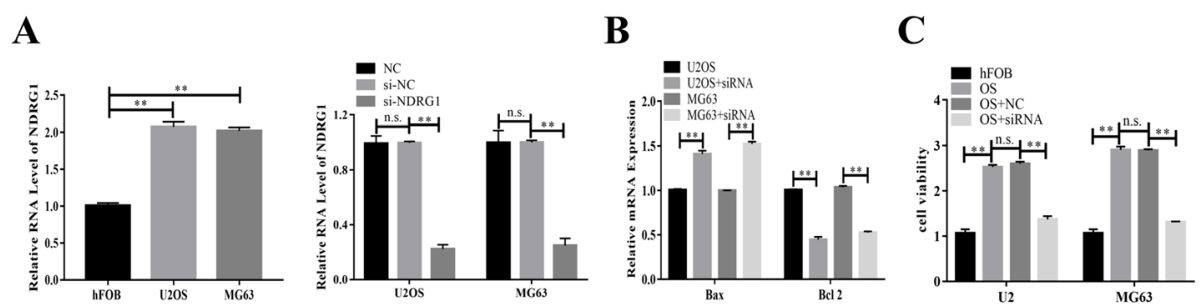

D

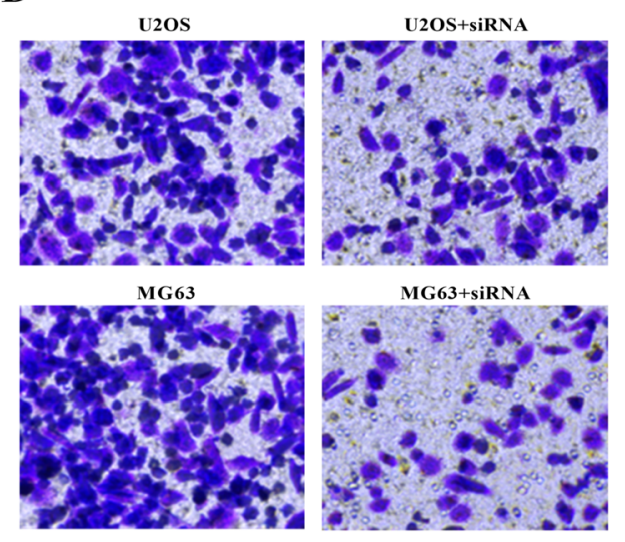

F
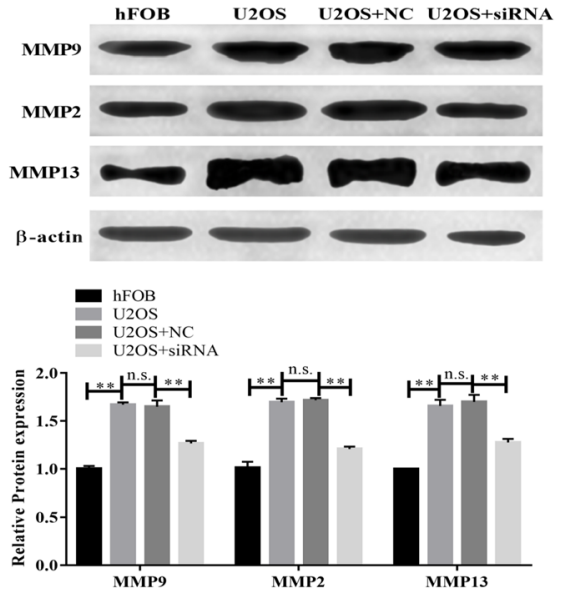

$\mathbf{E}$

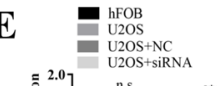

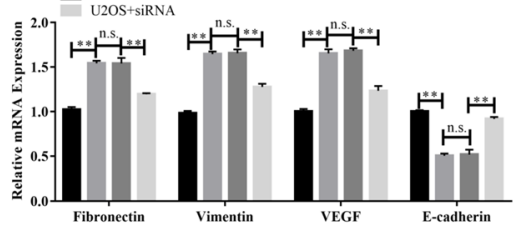

$\mathrm{hFOB}$
$\mathrm{MG} 63$
$\mathrm{MG} 63+\mathrm{NC}$
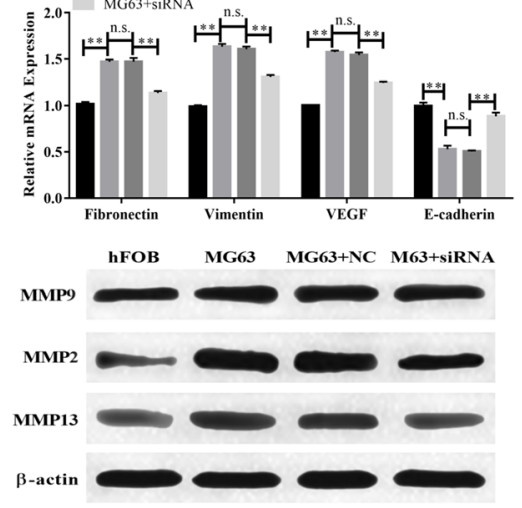

=

MG63

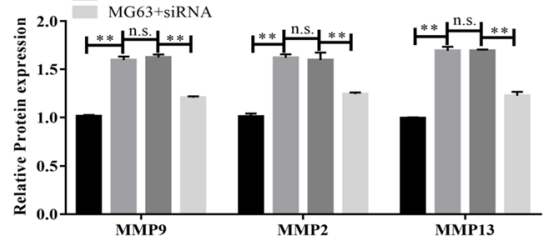

Fig. 1 Downregulation of NDRG1 expression promoted osteosarcoma cells migration, invasion. (A) The expression of NDRG after siRNA in hFOB, U2OS, and MG63. (B) Effect of NDRG1 on cell apoptosis. (C) NDRG expression enhanced the OS cells viability. (D) NDRG positively correlated with OS cells invasion. (E) The mRNA levels of VEGF, E-cadherin, fibronectin, and vimentin were decreased by NDRG siRNA. (F) Protein levels of MMP2, MMP9, and MMP13 were downregulated by siRNA

sorting marked CD133. Tumor-sphere formation demonstrated successful enrichment of CD133+ (Fig. 3B). In different cell lines, the expression of NDRG1 was difference. The NDRG1 levels were enriched in CSCs further, and were higher than hFOB, MG63, and U2OS cells ( $\mathrm{p}<$ 0.01, Fig. 3C). And the siRNA of NDRG1 decreased the expression of NDRG1 (Fig. 3D). Compared with CSCs control group, the expression levels of Runx2, Osteri, Dlx5, Coll I were upregulated by NDRG1 siRNA, promoting the differentiation of CSCs, while sex determining region Y-box (SOX) 2, octamer-binding transcription factor (OCT) 4, NONAG, and kruppel-like factor (KLF) 4 expression levels were downregulated (Fig. 3E, F). The downregulation of NDRG1 in CSCs inhibited activation of Wnt signaling pathway. After NDRG1 downregulation, Wnt pathway activation was receded. The expression of wingless-type MMTV integration site family member (Wnt) 3a, ß-catenin, transcription factor (TCF) 4, LRP5/6, and lymphoid enhancer binding factor (LEF) 1 were decreased by siRNA. However, the recombination protein of Wnt3a played the opposite effect comparing with NDRG1 siRNA, the combination treatment of Wnt3a and siRNA neutralizes the role of siRNA and Wnt3a (Fig. 4A, B). 
A

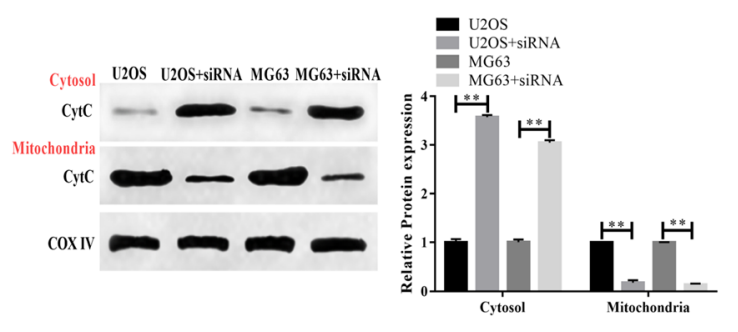

B

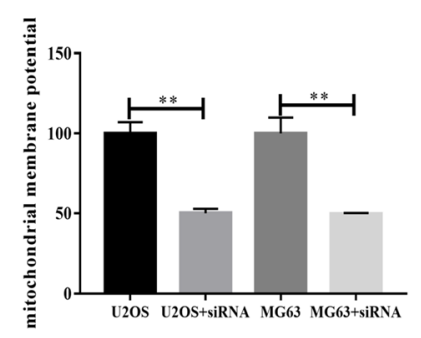

C

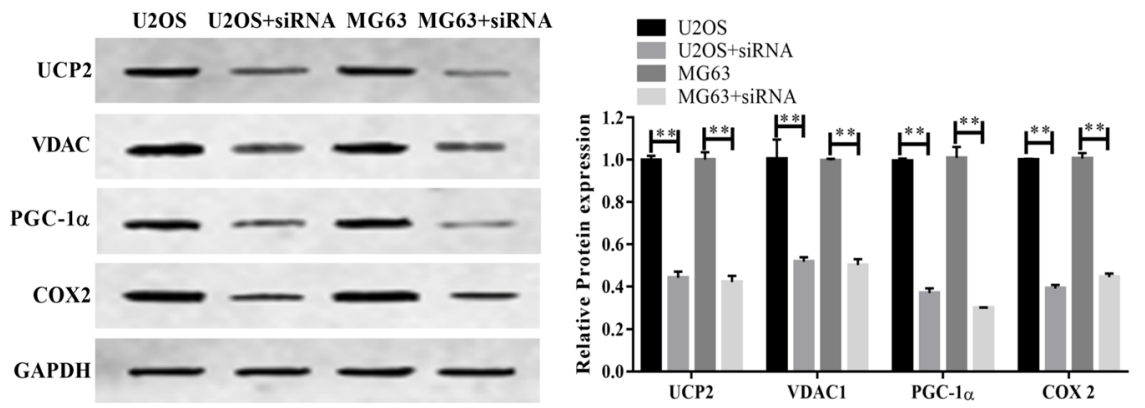

Fig. 2 Inhibition of NDRG activated the mitochondria-mediated apoptosis. (A) Changes of CytC in cytosol and mitochondria. (B) Mitochondrial membrane potential was declined when NDRG expression was inhibited. (C) UCP2, VDAC, PGC-1a, and COX2 were downregulated by siRNA

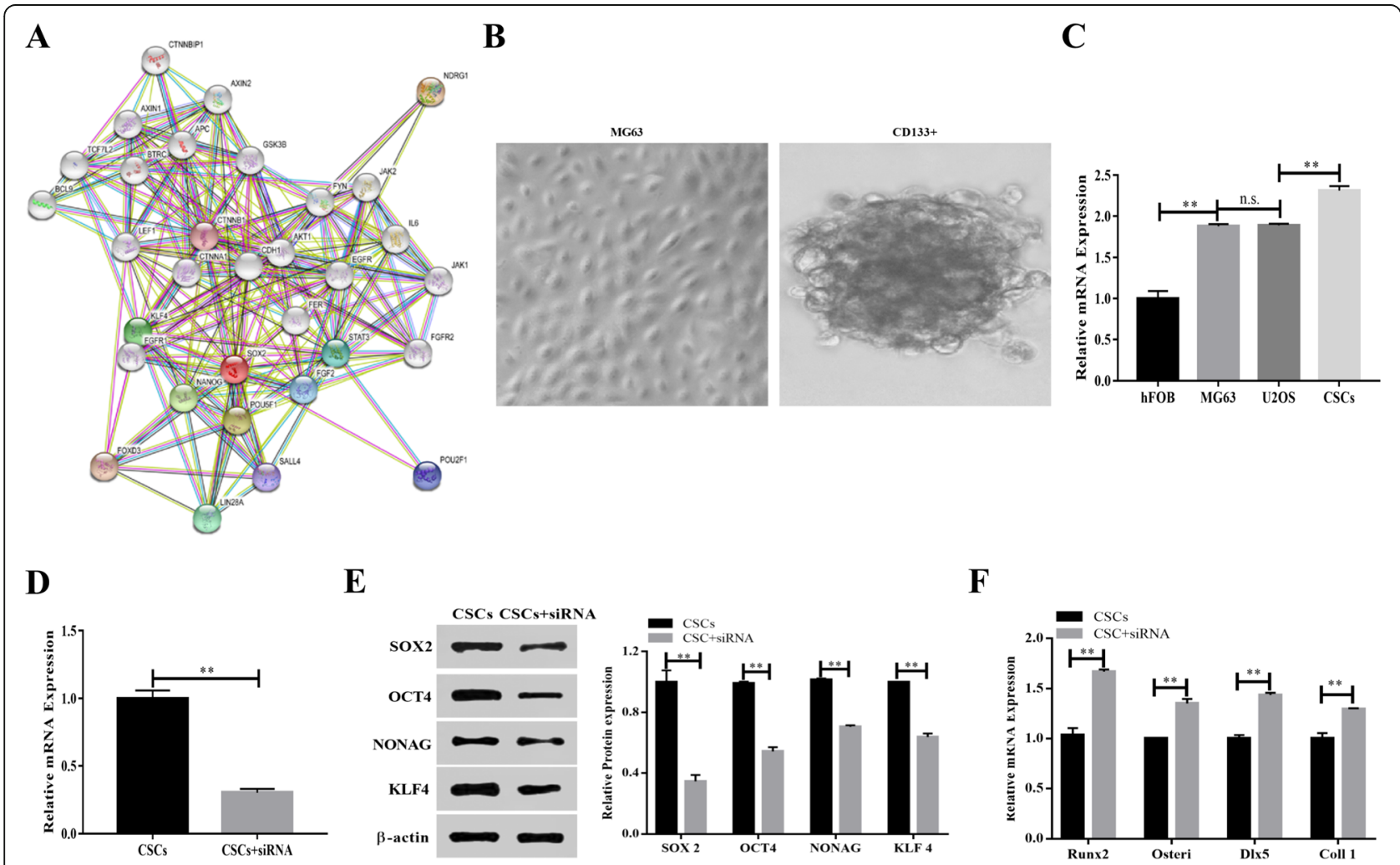

Fig. 3 NDRG1 expression maintained the CSCs stemness. (A) STRING was used to predict interaction between NDRG and SOX2. (B) Tumorformation assay for CD133+ positive cells. (C) The expression of NDRG1 in different cell lines. (D) NDRG1 siRNA downregulated NDRG1 in CSCs. (E) Silencing of NDRG1 reduced the pluripotency of CSCs. (F) Downregulation of NDRG1 promoted CSCs differentiation 


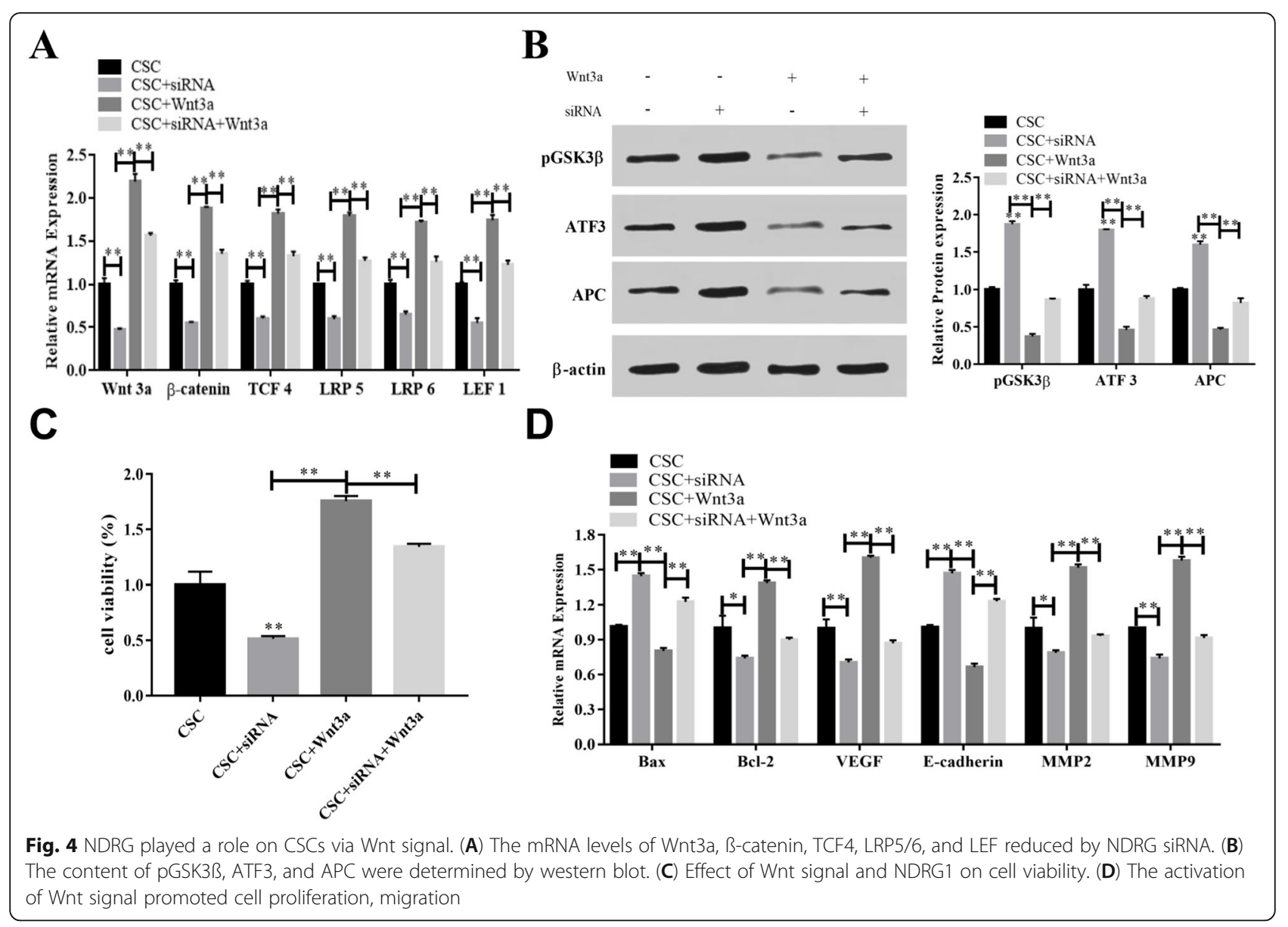

The activation of Wnt signal promoted the proliferation of CSCs, the cell apoptosis was reduced, and the expression of VEGF, MMP2, and MMP9 were upregulated. The treatment of si-NDRG1 increased the cell apoptosis, E-cadherin expression was upregulated (Fig. 4C, D).

\section{Discussion}

The cellular heterogeneity was observed in OS tumor samples and the presence of self-renewing subpopulations that did not respond to chemotherapy, which was attributed to CSCs [16]. These cells were characterized by the expression of pluripotency-related markers, such as SOX2 [17] and activation of signaling pathways that controlled stem cell self-renewal. Studies have found that all-trans retinoic acid inhibited the upregulation of CD117-Stro1 cells and CSC markers by M2-like macrophages, prevented the malignant transformation and differentiation of OS cells [18]. Most OS tumors are relatively undifferentiated. Therefore, induction of differentiation may be an interesting therapeutic strategy in that differentiated cells that may be more amenable to treatment. SOX2 is an essential factor in maintaining the undifferentiated state of OS cells and is critical for their self-renewal. And it is also an antagonist of the
Wnt pathway. Studies have shown that the tankyrase inhibitor JW74, which attenuated Wnt/ $\beta$-catenin activity, and induced U2OS cell differentiation, even though these cells were resistant to osteogenic differentiation under standard conditions [19].

NDRG1 played a role in OS cell differentiation and invasion [20], including inhibited tumor growth by modifying angiogenesis by reducing expression of the angiogenic gene VEGF [21]. NDRG1 expression was associated with MMP-2, -9, -10, and BCL2 apoptosis [22]. Recently, it was verified that the abnormal expression of NDRG4 was significantly associated with the biological function like ATP synthesis and mitochondrial membrane potential [23]. And the tumorigenesis potential of GBM CSCs was related to NDRG4 [24]. Moreover, the regulation of mitochondrial alternative oxidase expression could affect cell migration by changing of mitochondrial heat production [25]. The results of those researches were consistent with our primary hypothesis.

In the present study, the expression of NDRG1 was downregulated by siRNA treatment, and cell apoptosis increased. The protein expression of VEGF, E-cadherin, fibronectin, vimentin, and MMP were reduced. At the same time, mitochondria-dependent apoptosis was also 
induced by silencing of NDRG1, CytC was leaked in mitochondria and increased in cytosol. And the function of mitochondria was attenuated. In CSCs enriched by CD133-positive, the levels of SOX2, OCT4, NONAG, and KLF4 were bated by NDRG1 siRNA, accompanying the expression upregulation of differentiation related factors. The downregulation of NDRG1 inhibited the abnormal Wnt activation. Therefore, this research suggested that downregulation of NDRG1 inhibited the mitochondrial function and cell proliferation, migration. And the downregulation of NDRG1 promoted CSCs differentiation via regulating Wnt signal.

\section{Conclusion}

NDRG1 downregulation hampered the mitochondrial function, and decreased the invasive and metastatic ability of OS. In addition, silencing of NDRG1 reduced abnormal Wnt activation in tumors primarily, which promoted OS CSC differentiation, thus playing a role in regulating the cell cycle.

\section{Abbreviations}

CSCs: Cancer stem cells; OS: Osteosarcoma; NDRG1: N-myc downstream regulated gene 1; VEGF: Vascular endothelial growth factor; MMP2: Matrix metalloproteinase 2; MMPs: Mitochondrial membrane potential; UCP2: Uncoupling proteins 2; VDAC: Voltage dependent anion channel; PGC1a: Peroxisome proliferator-activated receptor gamma coactivator; COX2: Cyclooxygenase 2; CytC: Cytochrome C; SOX2: Sex determining region Y-box 2; OCT4: Octamer-binding transcription factor 4; KLF4: Kruppel-like factor 4; Wnt3a: Wingless-type MMTV integration site family member 3a; TCF4: Transcription factor 4; LEF1: Lymphoid enhancer binding factor 1

\section{Acknowledgements}

Thank you for scientific research project fund of colleges and universities in Gansu province (2018B-013) support.

\section{Authors' contributions}

Tong Zhao was responsible for manuscript writing and experiment conducting; Ying Meng contributed to data collection and analysis; Yongping Wang collected the literature and explained the results; Wenji Wang designed this study and reviewed this article. The authors read and approved the final manuscript.

\section{Funding}

This work was supported by the scientific research project fund of colleges and universities in Gansu province (2018B-013).

\section{Availability of data and materials}

The datasets supporting the conclusions of this article are included within the article.

\section{Declarations}

Ethics approval and consent to participate Not applicable.

\section{Consent for publication \\ Not applicable.}

\section{Competing interests}

The authors report no declarations of interest.

\section{Author details}

${ }^{1}$ The First Hospital of Lanzhou University, No. 1 Dongggang West Road, Chengguan District, Lanzhou, Gansu, China. ${ }^{2}$ Lanzhou University Second Hospital, Lanzhou, Gansu, China.

Received: 15 April 2021 Accepted: 23 May 2021

Published online: 07 June 2021

\section{References}

1. Xia P, X Gao, L Shao, Q Chen, F Li, C Wu, et al. Down-regulation of RAC2 by small interfering RNA restrains the progression of osteosarcoma by suppressing the Wnt signaling pathway. Int J Biol Macromol. 2019;137:122131. https://doi.org/10.1016/j.ijbiomac.2019.07.016.

2. Han C. and W Wang, MicroRNA-129-5p suppresses cell proliferation, migration and invasion via targeting ROCK1 in osteosarcoma. Mol Med Rep. 2018;17(3):4777-84. https://doi.org/10.3892/mmr.2018.8374

3. Kovacevic Z, Richardson DR. The metastasis suppressor, NDRG-1: a new ally in the fight against cancer. Carcinogenesis. 2006;27(12):2355-66. https://doi. org/10.1093/carcin/bgl146.

4. van Belzen N, Dinjens WN, Diesveld MP, Groen NA, van der Made AC, Nozawa $Y$, et al. A novel gene which is up-regulated during colon epithelial cell differentiation and down-regulated in colorectal neoplasms. Lab Invest. 1997;77(1):85-92.

5. Piquemal D, Joulia D, Balaguer P, Basset A, Marti J, Commes T. Differential expression of the RTP/Drg1/Ndr1 gene product in proliferating and growth arrested cells. Biochim Biophys Acta. 1999;1450(3):364-73. https://doi.org/1 0.1016/S0167-4889(99)00056-7.

6. Melotte V, Qu X, Ongenaert M, van Criekinge W, de Bruïne AP, Baldwin HS, et al. The N-myc downstream regulated gene (NDRG) family: diverse functions, multiple applications. FASEB J. 2010;24(11):4153-66. https://doi. org/10.1096/fj.09-151464.

7. Zhang ZY, Zhang SL, Chen HL, Mao YQ, Li ZM, Kong CY, et al. The upregulation of NDRG1 by HIF counteracts the cancer-promoting effect of HIF in VHL-deficient clear cell renal cell carcinoma. Cell Prolif. 2020;53(7):e12853.

8. Liu J, Zhu C, Zhang L, Lu H, Wang Z, Lv J, et al. MicroRNA-1469-5p promotes the invasion and proliferation of pancreatic cancer cells via direct regulating the NDRG1/NF-KB/E-cadherin axis. Human cell. 2020;33(4):117685.

9. Geleta B, Park KC, Jansson PJ, Sahni S, Maleki S, Xu Z, et al. Breaking the cycle: targeting of NDRG1 to inhibit bi-directional oncogenic cross-talk between pancreatic cancer and stroma. FASEB J. 2021;35(2):e21347.

10. Ledet RJ, Ruff SE, Wang Y, Nayak S, Schneider JA, Ueberheide B, et al. Identification of PIM1 substrates reveals a role for NDRG1 phosphorylation in prostate cancer cellular migration and invasion. Commun Biol. 2021;4(1): 36.

11. Guo DD, Xie KF, Luo XJ. Hypoxia-induced elevated NDRG1 mediates apoptosis through reprograming mitochondrial fission in HCC. Gene. 2020; 741:144552. https://doi.org/10.1016/j.gene.2020.144552.

12. Wang $Y$, Zhou Y, Tao F, Chai S, Xu X, Yang Y, et al. N-myc downstream regulated gene 1 (NDRG1) promotes the stem-like properties of lung cancer cells through stabilized c-Myc. Cancer Lett. 2017;401:53-62. https://doi.org/1 0.1016/j.canlet.2017.04.031

13. Ai R, Sun Y, Guo Z, Wei W, Zhou L, Liu F, et al. NDRG1 overexpression promotes the progression of esophageal squamous cell carcinoma through modulating Wnt signaling pathway. Cancer Biol Ther. 2016;17(9):943-54.

14. Sun J, Zhang D, Bae DH, Sahni S, Jansson P, Zheng Y, et al. Metastasis suppressor, NDRG1, mediates its activity through signaling pathways and molecular motors. Carcinogenesis. 2013;34(9):1943-54. https://doi.org/10.1 093/carcin/bgt163.

15. Wang H, Li W, Xu J, Zhang T, Zuo D, Zhou Z, et al. NDRG1 inhibition sensitizes osteosarcoma cells to combretastatin A-4 through targeting autophagy. Cell Death Dis. 2017:8(9):e3048.

16. Martins-Neves SR, Paiva-Oliveira DI, Fontes-Ribeiro C, Bovée JVMG, CletonJansen AM, CMF Gomes. IWR-1, a tankyrase inhibitor, attenuates Wnt/ $\beta$ catenin signaling in cancer stem-like cells and inhibits in vivo the growth of a subcutaneous human osteosarcoma xenograft. Cancer Lett. 2018;414:1-15.

17. Skoda J, Nunukova A, Loja T, Zambo I, Neradil J, Mudry P, et al. Cancer stem cell markers in pediatric sarcomas: Sox 2 is associated with tumorigenicity in immunodeficient mice. Tumour Biol. 2016;37(7):9535-48. https://doi.org/10.1 007/s13277-016-4837-0. 
18. Shao XJ, SF Xiang, YQ Chen, N Zhang, J Cao, H Zhu, et al. Inhibition of M2like macrophages by all-trans retinoic acid prevents cancer initiation and stemness in osteosarcoma cells. Acta Pharmacol Sinica. 2019;40(10):1343-50.

19. Stratford EW, Daffinrud J, Munthe E, Castro R, Waaler J, Krauss S, et al. The tankyrase-specific inhibitor JW74 affects cell cycle progression and induces apoptosis and differentiation in osteosarcoma cell lines. Cancer Med. 2014 3(1):36-46. https://doi.org/10.1002/cam4.170.

20. Vaes N, Schonkeren SL, Brosens E, Koch A, McCann CJ, Thapar N, et al. A combined literature and in silico analysis enlightens the role of the NDRG family in the gut. Biochimica et biophysica acta. Gen Subj. 2018;1862(10): 2140-51. https://doi.org/10.1016/j.bbagen.2018.07.004.

21. Zarrinpashneh E, Poggioli T, Sarathchandra P, Lexow J, Monassier L,

Terracciano C, et al. Ablation of SGK1 impairs endothelial cell migration and tube formation leading to decreased neo-angiogenesis following myocardial infarction. Plos One. 2013;8(11):e80268

22. de Lima JM, Morand GB, CCS M, Diesel L, Hier MP, Mlynarek A, et al. NDRG1 deficiency is associated with regional metastasis in oral cancer by inducing epithelial-mesenchymal transition. Carcinogenesis. 2020;41(6):769-77.

23. Shi HH, Liu HE, Luo XJ. Hypermethylation-mediated silencing of NDRG4 promotes pancreatic ductal adenocarcinoma by regulating mitochondrial function. BMB Rep. 2020;53(12):658-63. https://doi.org/10.5483/BMBRep.202 0.53 .12 .168 .

24. Schilling SH, Hjelmeland AB, Radiloff DR, Liu IM, Wakeman TP, Fielhauer JR, et al. NDRG4 is required for cell cycle progression and survival in glioblastoma cells. J Biol Chem. 2009;284(37):25160-9. https://doi.org/10.1 074/jbc.M109.012484.

25. Andjelković A, Mordas A, Bruinsma L, Ketola A, Cannino G, Giordano L, et al. Expression of the alternative oxidase influences Jun $\mathrm{N}$-terminal kinase signaling and cell migration. Mol Cell Biol. 2018;38(24):e00110-18. https:// doi.org/10.1128/MCB.00110-18

\section{Publisher's Note}

Springer Nature remains neutral with regard to jurisdictional claims in published maps and institutional affiliations.

Ready to submit your research? Choose BMC and benefit from:

- fast, convenient online submission

- thorough peer review by experienced researchers in your field

- rapid publication on acceptance

- support for research data, including large and complex data types

- gold Open Access which fosters wider collaboration and increased citations

- maximum visibility for your research: over $100 \mathrm{M}$ website views per year

At $\mathrm{BMC}$, research is always in progress.

Learn more biomedcentral.com/submissions 